\title{
Lordship and State Formation \\ Bohemia and the Habsburg monarchy from the Thirty Years' War to Charles VI ${ }^{1}$
}

\author{
STEPHAN SANDER-FAES
}

\section{Introduction}

The decades around 1700 were decisive for both Central Europe and its major power, the Habsburg monarchy. Much has been written about its main events and protagonists from the Ottoman siege of Vienna and the subsequent pushback of Christendom's „hereditary enemy“ across the Hungarian plains, and the contemporaneous wars against Louis XIV's France, which culminated in the greatest territorial extent of the Austrian monarchy in the early $18^{\text {th }}$ century. ${ }^{2}$ Hardly surprising, the historiography of this era is extensive, and in many cases very lopsided, yet despite the amounts of ink that have been spilled over the Habsburg monarchy's so-called „Age of Heroes“, or Heldenzeitalter, there are also blind spots: Perhaps echoing much of the older literature, even most newer studies continue to focus on „big men“ and their actions at court, in the various diets, or on the many battle fields, often more or less influenced by the Cultural Turn, which resulted in the publication of a wide variety of studies highlighting the serious limitations of Habsburg absolutism, emphasising the symbolic characteristics of their rule, and offering systemic explanations for the changes in the wake of the Thirty Years'War. This holds particularly true for the Westphalian treaties, viewed by many, historians and scholars in fields as diverse as International Relations, Political Science, Legal History, and Sociology alike as the foundation of our "modern“ era. ${ }^{3}$ If there is a common thread that unites virtually all of these studies, it is

1 I would like to express my gratitude to Václav Bůžek and Opera historica for affording me the opportunity to present the major findings of my recently-completed professorial thesis, or Habilitationsschrift, entitled Herrschaft und Staatlichkeit: Böhmen in der Habsburgermonarchie vom Dreißigjährigen Krieg bis Karl VI., and submitted to the Faculty of Arts, University of Zurich, in October 2017. If not noted specifically, all translations are by the author.

2 The best general introduction is Robert John Weston Evans, The Habsburgs and Central Europe, 1683-1723, in: idem (ed.), Austria, Hungary, and the Habsburgs. Essays on Central Europe, c. 1683-1867, Oxford 2006, p. 3-14; Charles W. Ingrao, The Habsburg Monarchy, 1618-1815, Cambridge 2005, p. 105-149; most recently Thomas Win kelbauer, Die Habsburgermonarchie vom Tod Maximilians I. bis zum Aussterben der Habsburger in männlicher Linie (1519-1740), in: Thomas Winkelbauer (ed.), Geschichte Österreichs, Stuttgart 2015, p. 159-289.

3 Michael Hochedlinger, Austria's Wars of Emergence. War, State, and Society in the Habsburg Monarchy, 1683-1797, London 2003, p. 5-202, including bibliography; Heinz DurchrardT, The Peace of Westphalia. A European Peace, in: Olaf Asbach - Peter Schröder (edd.), The Ashgate Research Companion to the Thirty Years'War, Farnham 2014, p. 309-318; Gabriele Haug-Moritz, 1648 - 
their perception of early modern Europe from its courtly centres or from within the central governments, usually guided by the deeds of important events and their protagonists. ${ }^{4}$ Whereas this conceptual framing is a perfectly valid and timetested one, it comes with serious limitations: Given the various main actors' social background, their aristocratic perception of the world, and their overwhelmingly courtly and urban outlooks, their sources are limited in scope, which further reduces the historian's interpretative leeway and, potentially, leads to reductionist analyses based on anachronistic assumptions. ${ }^{5}$

Using the example of Bohemia - aguably the most important of the Habsburgs' possessions - during the Austrian monarchy's emergence as a great power, my study focuses on the usually overlooked by-products of state formation in early modern composite monarchies. ${ }^{6}$ Whereas expansion of enquiry into the "fiscal-military state" (John Brewer) ${ }^{7}$ and

Der Westfälische Frieden, das Heilige Römische Reich und die Habsburgermonarchie, in: Martin Scheutz - Arno Strohmeyer (edd.), Von Lier nach Brüssel. Schlüsseljahre österreichischer Geschichte (1496-1995), Innsbruck 2010, p. 99-110, including bibliography.

4 While Austrian historiography was Vienna-centred from its inception, two recent examples underscore this point: $\mathrm{cf}$. the configuration of a multi-vol. handbook on the monarchy's administrative history currently prepared by the Austrian Institute of Historical Research and the Academy of Sciences: vol. 1 deals with the court and the central institutions, vol. 2 comprises the various crown lands' central institutions, and vol. 3 focuses on, among other aspects, local governance and regional varieties. Thomas Win Kelbauen, „Verwaltungsgeschichte der Habsburgermonarchie in der Frühen Neuzeit" in drei Bänden - ein groß angelegtes internationales Kooperationsprojekt, in: Michael Hochedlinger - Thomas Winkelbauer (edd.), Herrschaftsverdichtung, Staatsbildung, Bürokratisierung. Verfassungs-, Verwaltungs- und Behördengeschichte der Frühen Neuzeit, Vienna 2010 (= Veröffentlichungen des Instituts für Österreichische Geschichtsforschung 57), p. 9-17, especially p. 11-14; cf. the complete omission of local and regional issues by Zdislava RöHSner, Die zentrale Finanzverwaltung der Monarchie, in: Stefan Seitschek - Herbert Hutterer - Gerald Theimer (edd.), 300 Jahre Karl VI., 1711-1740. Spuren der Herrschaft des „letzten“ Habsburgers, Vienna 2011, p. 112-118.

5 Cf. the point made by Benno Tesch кe, Revisiting the „War-Makes-States“Thesis. War, Taxation and Social Property Relations in Early Modern Europe, in: Olaf Asbach - Peter Schröder (edd.), War, the State and International Law in Seventeenth Century Europe, Burlington 2010, p. 35-62, here p. 43-44.

6 John Elliott, A Europe of Composite Monarchies, Past \& Present 137, 1992, p. 48-71; Klaus SchreIner, Grundherrschaft - ein neuzeitlicher Begriff für eine mittelalterliche Sache, in: Gerhard Dilcher - Cinzio Violante (edd.), Strukturen und Wandlungen der ländlichen Herrschaftsformen vom 10. zum 13. Jahrhundert. Deutschland und Italien im Vergleich, Berlin 2000 (= Schriften des Italienisch-Deutschen Historischen Instituts in Trient 14), p. 69-93, here p. 87.

7 John Brewer, The Sinews of Power. War, Money and the English State 1688-1783, London 1989; for guidance to the large and growing body of work in his mould start with Christopher STORRs (ed.), The Fiscal-Military State in $18^{\text {th }}$-Century Europe, Farnham 2009; see also, for example Bartolomé Yun-Casalilla - Patrick K. O'Brien (edd.), The Rise of Fiscal States. A Global History 1500-1914, Cambridge 2012; and, most recently, Aaron Graham - Patrick Walsh (edd.), The British Fiscal-Military States 1660-c.1783, London 2016, esp. the introduction on p. 1-25. 
the shattering of the Myth of Absolutism across Europe have transformed our understanding of central bureaucracies over the course of the past three decades, an overwhelming number of studies on early modern state formation continues to employ a top-down perspective. ${ }^{8}$ By contrast, my book approaches one of historiography's late-comers to this debate, the Habsburg monarchy, based on two distinctively different premises: ${ }^{9}$ First, individual actions as well as structural developments convey different - and differing - consequences for central institutions vis-à-vis those occurring contemporaneously in administratively and geographically more remote areas. It follows, second, that state integration, understood as an elite-driven process emanating from the centre of power, is accompanied by countervailing and at times opposing trends and pressures whose consequences only increased with geographical distance. Warfare, above all, concentrates decision-making and influence in the hands of a limited number of individuals and institutions while non-essential considerations (temporarily) recede: Armed conflict thus gives rise to a certain kind of state formation, which was accompanied by a contemporaneous disintegration and loss of cohesion outside the corridors of power. In short, my study explores, how, as the central government tried to cope with war-induced stresses, its actions started to tear apart the administrative and social fabric that held society together. ${ }^{10}$

My study focuses on the interrelated aspects of bureaucratic practices, war, and taxation from the perspective of the

8 Nicholas Henshall, The Myth of Absolutism. Change and Continuity in Early Modern European Monarchy, London 1992; on its impact on German scholarship see the essays in Ronald G. AscH - H. Duchnardt (edd.), Der Absolutismus - ein Mythos? Strukturwandel monarchischer Herrschaft in West-und Mitteleuropa, ca. 1550-1700, Cologne 1996 (= Münstersche Historische Forschungen 9), which did not include the Austrian monarchy; for guidance to the most recent contributions see the essyays in Lothar Schilling (ed.), Absolutismus, ein unersetzliches Forschungskonzept? Eine deutsch-französische Bilanz/L'absolutisme, un concept irremplaçable? Une mise au point franco-allemand, Munich 2014 (= Pariser historische Studien 79).

9 Start with the essays in Petr Maťa - Thomas Winkelbauer (edd.), Die Habsburgermonarchie, 1620-1740. Leistungen und Grenzen des Absolutismusparadigmas, Stuttgart 2006 (= Forschungen zur Geschichte und Kultur des östlichen Mitteleuropa 24), especially the introduction on p. 7-42, including bibliography.

10 Noted by J. BREwer, The Sinews of Power, p. 138: „We need to remember that the act of waging war did not inevitably lead to the development of new and more powerful state institutions. Indeed, in early modern Europe war often succeeded in diluting rather than concentrating state power." Cf. similar assessments by Victoria TIN-Bor HuI, War and State Formation in Ancient China and Early Modern Europe, New York 2005, p. 48-49; B. Tеsснкe, Revisiting, p. 58; with the findings of military historians summarised by Bernhard Kroener, Kriegswesen, Herrschaft und Gesellschaft, 1300-1800, Munich 2013 (= Enzyklopädie deutscher Geschichte 92), p. 104-105: „Though borne by the spirit of the $19^{\text {th }}$ century, the assertion that war and the military, based on administrative thickening, were the main pillars of early modern state development and thus unequivocally point to the modern bureaucratic state... cannot be sustained." 
composite lordship of the Eggenberg dukes of Český Krumlov. ${ }^{11}$ Since the late Middle Ages, these territories formed a relatively large - in all c. 390 square kilometres (about the size of St Vincent and the Grenadines and a good deal larger than, say, Malta) - and comparatively contiguous territorial agglomeration, and its respective owners - the Rosenbergs (from the $13^{\text {th }}$ century to around 1600 ), the Eggenbergs (1623-1710/19), and Schwarzenbergs (1723-1948/49) - were among the most powerful lords in the Bohemian lands. ${ }^{12}$ These large continuities resulted in equally vast archival holdings that, despite their exceptional richness in both quantitative as well as qualitative regards, remain seriously under-used to this day for two reasons. While this neglect is also in part attributable to the ideologically limiting conceptual and thematic predispositions of the Cold War, the archive's neglect since the Velvet Revolution (1989) has other sources (even though quite similar consequences): Many sources from the early modern period up until the Czech National Revival in the early $19^{\text {th }}$ century in those areas that until 1945 were inhabited by Germans were written in German, and during the Communist era (1948-89) the first foreign language taught in schools was Russian, which was replaced with English after the Iron Curtain came down, leaving large amounts of primary sources with only a very limited and, over time, further decreasing number of readers and researchers. ${ }^{13}$ In addition and with only very few exceptions - most importantly the studies by Eduard Maur and Jaroslav Čechura - , since the 1990s most Czech historians focused on the early modern aristocratic body politic and their assemblies; ${ }^{14}$ and while the owners of Český Krumlov were among the most

11 Topographical information follows present-day conventions, homonyms follow common usage in English; exceptions are those places generally familiar, e.g. Vienna or Prague; pertinent information from primary sources is reproduced as in the original with additional information, if helpful or necessary, added in parentheses.

12 See the overview provided in Pavel JuŘík, Jihočeské dominium. Rožmberkové, Eggenbergové, Schwarzenbergové a Buquoyové v jižnich Čechách, Prague 2008, on the Eggenberg especially p. 103-119.

13 Václav BůžEK, Frübneuzeitliche Adelsgeschichte in der tschechischen Geschichtsscbreibung, in: Ronald G. Asch - Václav Bůžek - Volker Trugenberger (edd.), Adel in Südwestdeutschland und Böhmen (1450-1850), Stuttgart 2013 (= Veröffentlichungen der Kommission für geschichtliche Landeskunde in Baden-Württemberg, Reihe B, Forschungen 191), p. 261-288, here p. 270.

14 See the literature overview on administrative matters by Petr MAŤA, Verwaltungs- und behördengeschichtliche Forschungen zu den böhmischen Ländern in der Frühen Neuzeit. Kurzer Überblick über vier lange Forschungstraditionen, in: M. Hochedlinger - T. Winkelbauer (edd.), Herrschaftsverdichtung, p. 421-477; on Bohemian taxes specifically IDEM, „Unerträgliche Praegravation. “Steuererhebung und Militärfinanzierung im Königreich Böbmen vom Dreißigjäbrigen Krieg bis zum Regierungsantritt Maria Theresias, in: Peter Rauscher (ed.), Kriegsführung und Staatsfinanzen. Die Habsburgermonarchie und das Heilige Römische Reich vom Dreißigjährigen Krieg bis zum Ende des habsburgischen Kaisertums 1740, Münster 2010 (= Geschichte in der Epoche Karls V. 10), p. 139-185, especially p. 148-157; the "other side“ of these historiographic developments is commented on by Markus 
powerful lords throughout the Middle Ages and the early modern period, the loss of the Eggenberg family archive appears dissuasive to most historians interested in aristocratic history, even though its incredibly rich holdings, and especially the examination of its administrative sources, yields so many new insights. ${ }^{15}$

Given these circumstances, and the fact that Charles Tilly's dictum - that „war made the state, and the state made war" ${ }^{\text {"16 }}$ - is generally, though no longer uncritically, accepted, there exists no large-scale study on the Habsburg experience of state formation between the Thirty Years' War and the reign of Charles VI that does not (and almost exclusively so) focus on the imperial court and/or on the various provincial estates and their assemblies (or Ständeforschung). ${ }^{17}$ Adopting a novel perspective from outside these circles, and by tapping into these rich seams of archival sources that have not been mined before, my study offers an innovative approach to specialist discussions on early modern state formation while at the same time provides a window into areas that are

Cerman, Untertanen, Herrschaft und Staat in der Frühen Neuzeit, in: idem - Robert Luft (edd.), Untertanen, Herrschaft und Staat in Böhmen und im „Alten Reich“. Sozialgeschichtliche Studien zur frühen Neuzeit, Munich 2005 (= Veröffentlichungen des Collegium Carolinum 99), p. 1-27; see also the synthesis by Eduard Maur, Staat und (lokale) Gutsherrschaft in Böhmen (1650-1750), in: ibidem, p. 31-50; and IDEM, Der Staat und die lokalen Grundobrigkeiten. Das Beispiel Böhmen und Mähren, in: P. Mata - T. Winkelbauer (edd.), Die Habsburgermonarchie, p. 443-453.

15 Walther E. Heydendorf, Die Fürsten und Freiherren zu Eggenberg und ihre Vorfahren, Graz 1965, especially p. 61-188; the two unpublished theses by Gerhard B. Marauscheк, Die Fürsten zu Eggenberg. Unter besonderer Berücksichtigung ihres Kunstmäzenatentums (1568-1717), Graz 1968, especially p. 153-209; Martin Mutschlechner, Die Fürsten von Eggenberg als Herzöge von Krumau. Kontinuität und Wandel in Südböhmen im 17. Jahrhundert, Vienna 2007; there is no new large-scale study on the Eggenberg dukes, though Pavel Himl, Die „armben Leüte“ und die Macht. Die Untertanen der südböhmischen Herrschaft Český Krumlov/Krumau im Spannungsfeld zwischen Gemeinde, Obrigkeit und Kirche (1680-1781), Stuttgart 2003 (= Quellen und Forschungen zur Agrargeschichte 48) offers invaluable insights into their (and their heirs') possessions; see also n. 12; on the archival riches cf. S. SANDER-FaEs, Herrschaft und Staatlichkeit, p. 61-65.

16 Charles Tilly, Reflections on the History of European State-Making, in: idem (ed.), The Formation of the National State in Western Europe, Princeton 1975 (= Studies in Political Development 8), p. 3-83, here p. 42.

17 Based on Gerhard Dietrich (ed.), Ständische Vertretungen in Europa im 17. und 18. Jahrhundert, Göttingen 1969; there are innumerable studies on Europe's major powers such as France or Prussia, while the Habsburg monarchy was mostly left out; e.g. John Russell Major, From Renaissance Monarchy to Absolute Monarchy. French Kings, Nobles, and Estates, Baltimore 1994; Peter BaumgarT (ed.), Ständetum und Staatsbildung in Brandenburg-Preussen, Berlin 1983 (= Veröffentlichungen der Historischen Kommission zu Berlin 55); on Austria now see the essays by Mark Hengerer, Michael Hochedlinger, and Petr Mata. P. MaŤa - T. Winkelbaue r, Habsburgermonarchie, as well as the contributions to Gerhard AmMerer et al. (ed.), Bündnispartner und Konkurrenten der Landesfürsten? Die Stände der Habsburgermonarchie, Vienna 2007 (= Veröffentlichungen des Instituts für österreichische Geschichtsforschung 49). 
usually treated either rather lop-sidedly or mostly ignored..$^{18}$ In focusing on the princely officials and subjects as they tried to navigate the stormy passages of rising taxation and increasing pressures emanating from Vienna and Prague, I am addressing the following main questions: What where the consequences of the emperors' wars on local and regional taxation levels? How did the increasing tax burden manifest itself and how did the officials and subjects deal with it? How did the course of events and the accompanying structural developments affect both the various local, regional, and supra-regional interlinkages? And, lastly, the inclusion of questions dealing with the production and use of information and more qualitative issues like perceptions also allows for an assessment of the established, but still largely unanswered question of how ordinary people dealt with the massive tax hikes.

\section{Bohemia in the Habsburg monarchy in the $17^{\text {th }}$ Century}

Over the course of the Thirty Years' War, Bohemia changed drastically. The Estates' revolt was followed by large-scale redistributions of property, and the longer the conflict dragged on, the higher the damages the country and its inhabitants had to endure. When the dust finally settled, the Bohemian Lands had lost about a third of its people and large areas, especially in the fertile central regions, were most severely affected. ${ }^{19}$ While the extraordinary wartime measures were gradually abrogated over the course of the early 1650s, a return to the status quo ante appeared all but impossible. Consequently, both crown and estates cooperated closely to reorganise the kingdom's tax administration, which after a multi-year effort yielded a new cadastre, the so-called Berni rula, or Steuerrolle. Promulgated in 1656 and revised in 1683, it contained the numbers of tax-paying

18 See, e.g., the essays in Wim Blockmans - André Holenstein - Jon Mathieu (edd.), Empowering Interactions. Political Cultures and the Emergence of the State in Europe (1300-1900), Farnham 2009, that all but omit the Austrian monarchy; now, while including the Habsburgs' lands, the essays in Stefan Brakensiek - Corinna von Bredow - Birgit NäTHER (edd.), Herrschaft und Verwaltung in der Frühen Neuzeit, Berlin 2014 (= Historische Forschungen Duncker und Humblot 101), do not include the period before 1750 (at p. 19-20); see also, based on Niklas Luhmann's theories, the contributions in Stefan HaAs - Mark Hengerer (edd.), Im Schatten der Macht. Kommunikationskulturen in Politik und Verwaltung (1600-1950), Frankfurt am Main 2008, that employ a top-down perspective.

19 Ronald John Weston Evans, The Habsburgs and Bohemia, 1526-1848, in: idem (ed.), Austria, Hungary, and the Habsburgs, p. 75-98, including bibliography; Jiří Mi кulec, Baroque Absolutism (16201740), in: Jaroslav Pánek - Oldřich Tůma et al. (edd.), A History of the Czech Lands, Prague 2009, p. 231-259, including bibliography; on the Counter-Reformation Harold Louthan, Converting Bohemia. Force and Persuasion in the Catholic Reformation, Cambridge 2011; on the redistribution of property Tomáš Knoz, Pobèlohorské konfiskace. Moravský průbèh, středoevropské souvislosti, obecné aspekty, Brno 2006; population numbers according to Karl Richter, Die böhmischen Länder von 1471 bis 1740, in: Karl Bosl (ed.), Handbuch der Geschichte der böhmischen Länder, Stuttgart 1974, here vol. II, p. 97-412, at p. 321-2. 
„units“ (osedly, or Angesessene) that remained the basis of taxation in Bohemia until the early eighteenth century. ${ }^{20}$ Thus similarly „renewed“, the kingdom's tax system underwent considerable change during Leopold I's reign: During the second half of the $17^{\text {th }}$ century, Bohemian taxes became increasingly differentiated as both the military tax, or Contribution, and many other levies were specifically earmarked for certain purposes that ranged from extraordinary war taxes to more regular sums for the fortifications of Prague and Cheb to the salaries of officials throughout the country to wedding presents, all payable on specified dates. ${ }^{21}$ These specifics remained fundamentally unaltered until the reforms under Maria Theresa, yet this briefest of sketches allows us to recognise the essential dynamic of the Monarchy's fiscal-financial history after the mid- $17^{\text {th }}$ century: As time went on, the emperor engaged in more wars that, at the same time, became ever more costly. As regards Bohemia, the kingdom's tax levels roughly sextupled from about 300,000 to 350,000 fl. annually in the early 1650 s to about $1.8 \mathrm{~m}$ around the turn of the century. ${ }^{22}$

\section{Lordship and State (De-) Formation}

Tax returns from the large Eggenberg possessions, however, mirror these developments only partially: Overall taxation rose rapidly during the first decade after the promulgation of the Berni rula (1657-66) before dropping equally fast below pre-war (1663/64) levels; a much closer correlation between Český Krumlov's taxation vis-à-vis the kingdom of Bohemia as a whole only emerged during the 1670s. Table 1 details the annual total tax receipts from the Eggenberg possessions during the second half of the $17^{\text {th }}$ century; these comprise both contributions as well as other regular and extraordinary levies;

20 The standard treatment remains Josef PEKAř, České katastry, 1654-1789. Se zvláš́tním zřetelem $k$ dẽjinám hospodářským a ústavním, Prag 1932, p. 4-56; see also P. MAŤA, „Unerträgliche Praegravation“, p. 157-183; the recent synthesis by Jean BÉREnger, Les Habsbourg et l'argent. De la Renaissance auf Lumières, Paris 2014, especially p. 249-302; based on IDEM, Finances et absolutisme autrichien dans la seconde moitié du $17^{e}$ siècle, Paris 1975; and IDEM, À propos d'un ouvrage récent. Les finances de l'Autriche à l'époque baroque (1650-1740), Histoire, économie et societé 3, 1984, p. 221-245.

21 On the extraordinary war taxes J. РекAг̌, České katastry, p. 24-26, on the fortifications p. 63-66; P. MA「̌A, „Unerträgliche Praegravation“, p. 162-164; a wedding present was granted on Leopold's first marriage to Margarita Teresa of Spain in 1666, see Státní oblastní archiv Třeboň [State Regional Archive in Třebon], oddělení Český Krumlov [Satellite Office Český Krumlov], Vrchní úřad - česká generália [Estate directorate - Common Bohemian Documents], sign. I 4 L $\alpha$, fasc. 62, s.p., Repartitiones, 1665; there were other gifts to, e.g., Joseph I in 1699; Vrchní úřad - česká generália, I 4 L $\alpha, 64$, s.p., Auszug der Steuern, 1682-1701, Ceský Krumlov, s.d.

22 General treatment by Thomas Winkelbauer, Ständefreibeit und Fürstenmacht I-II. Länder und Untertanen des Hauses Habsburg im Konfessionellen Zeitalter, 1522-1699, Vienna 2003, here I, p. 449529; IDEM, Nervus rerum austriacarum. Zur Finanzgeschichte der Habsburgermonarchie um 1700, in: P. Mata - T. Winkelbauer, Habsburgermonarchie, p. 179-215; recently summarised in IDEM, Krieg und Herrschaftsverdichtung in der Habsburgermonarchie nach dem Dreißigjährigen Krieg, in: Karin 
in addition, it also details year-onyear changes and the correspondingly calculated tax level per osedly. Figure
1, below, illustrates the divergence of Český Krumlov's tax history vis-à-vis developments for Bohemia:

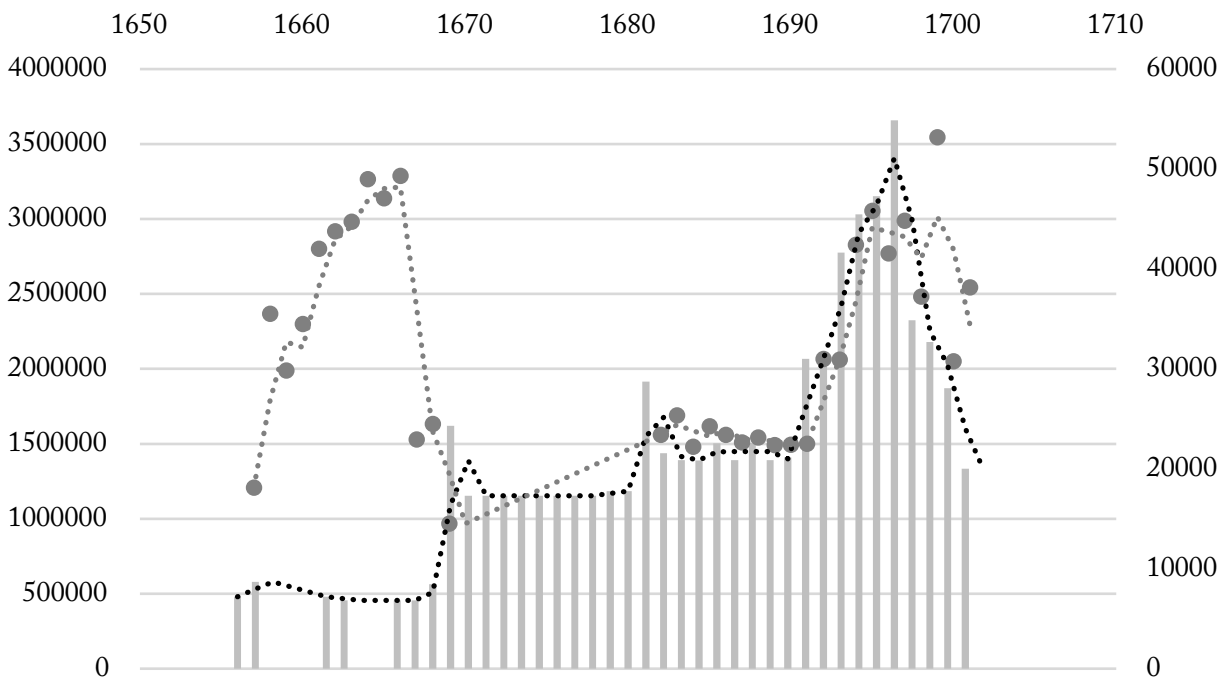

Fig. 1: Bohemian Taxes and Taxes paid by the Eggenberg Dukes, 1657-1701

Sources: Data for Český Krumlov based on Vú - čg, I 4 L $\alpha, 62,63,64,65$, and 66; data on Bohemia compiled from J. BÉrenger, À propos, p. 238 (1660; 1661; 1665; 1666; 1669-1680); IDEM, Les Habsbourg, p. 267 (1681-1700); and P. MAঙ̌A, „Unerträgliche Praegravation“, p. 163-170; the grey columns indicate the contributions granted by the Bohemian diet, the dotted black line their moving average; the gray dots represent tax payments from Český Krumlov; the dotted gray line their moving average; the left-hand side of fig. 1 refers to the Bohemian taxes, while the right-hand side refers to the Krumlovian taxes; note that the Bohemian data includes contributions, or military taxes, only, while data from Český Krumlov includes all taxes (in Rhenish fl.).

Chapter 4 aims at two main issues: $\quad$ First, a detailed reconstruction of how

Sperl - Martin Scheutz - Arno Strohmeyer (edd.), Die Schlacht von Mogersdorf/St. Gotthard und der Friede von Eisenburg/Vasvár. Rahmenbedingungen, Akteure, Auswirkungen und Rezeption eines europäischen Ereignisses, Eisenstadt 2016, p. 35-61; on Bohemia specifically P. MAŤA, „Unerträgliche Praegravation“, p. 169; J. BÉREnger, Les Habsbourg, p. 163-382, p. 261-273. 
known trends (higher taxes granted by the Bohemian diet) affected one area, the Eggenberg dominions; and, second, to lay the foundation for the following chapters. The main finding is that while there is a certain correlation between the state's increasing demand for taxes in wartime, there was no structural change in how the individual appropriations were administrated in neither the corporate institutions in Prague (the diet and the estates' institutions such as the royal tax office) and in the circles nor in the invidual lordships. This becomes immediately apparent if we follow the labyrinthine paths of tax appropriations: Once the diet discussed the monarch's proposals and eventually granted (parts of) them, the governor's office relayed them to the tax office where the total of each individual tax grant was repartitioned and passed on to the next lower administrative units; there, circle officials in turn repartitioned "their" sum again and then forwarded so-called „Assignationes" to the individual landlords, whose officials repeated the same process a third time - and all this happened before even a single fl. was collected. ${ }^{23}$ In Český Krumlov, the princely administrators oversaw comparatively large dominions whose tax history is then further broken down into its components. ${ }^{24}$ Moving the analysis beyond the traditional differentiation between military taxes, or contributions, and those additional levies due on specific dates is revealing on many accounts as the following table details:

\begin{tabular}{|c|c|c|c|c|}
\hline & $\Sigma^{\mathrm{a}}$ & no. of osedlýb & per osedlýc & $\mathrm{YoY}^{\mathrm{d}}$ \\
\hline 1657 & 18.130 & $2.6223 / 4$ & 7 & $\mathrm{n} / \mathrm{a}$ \\
\hline 1658 & 35.538 & $2.5381 / 4$ & 14 & +100 \\
\hline 1659 & 29.837 & $2.5841 / 2$ & $11 \frac{1 / 2}{2}$ & -18 \\
\hline 1660 & 34.487 & $2.576^{1 / 8}$ & $13 \frac{1 / 3}{3}$ & +16 \\
\hline 1661 & 42.041 & $2.5947 / 8$ & 16 & +20 \\
\hline 1662 & 43.796 & $2.526^{11 /{ }^{\mathrm{e}}}$ & 17 & +6 \\
\hline 1663 & 44.724 & $2.5481 / 2$ & 18 & +14 \\
\hline 1664 & 48.991 & $2.4581 / 2$ & 20 & +11 \\
\hline 1665 & 47.070 & $2.5951 / 8$ & 18 & -9 \\
\hline 1666 & 49.330 & $2.6063 / 8$ & 19 & +5 \\
\hline 1667 & 22.959 & $2.6063 /{ }_{8}^{\mathrm{e}}$ & 9 & -52 \\
\hline 1668 & 24.502 & $2.606{ }^{1 / 4}$ & 9 & \pm 0 \\
\hline
\end{tabular}

23 See the summary, albeit focused on the contributions only, in P. MA亡̌A, „Unerträgliche Praegravation“, p. 173-178; more details in Bohuslav Rieger, Zřizeni krajské v Čechach I. Historický vývoj do r. 1740, Prague 1889, p. 316-366; J. PeкǍ̌, České katastry, p. 25, 62, 77, 93.

24 If not indicated otherweise, based on S. SANDER-FaEs, Herrschaft und Staatlichkeit, p. 165-238. 


\begin{tabular}{|c|c|c|c|c|c|}
\hline 1669 & 14.518 & $2.5951 / 4$ & $51 / 2$ & -39 & \\
\hline 1682 & 23.415 & $2.6305 / 8$ & 9 & $\mathrm{n} / \mathrm{a}$ & \\
\hline \multirow[t]{2}{*}{1683} & 25.373 & $2.59815 /{ }_{16}^{f}$ & $10^{\mathrm{f}}$ & +43 & \\
\hline & & $1.668 \% / 8$ & $15^{\mathrm{g}}$ & & +214 \\
\hline 1684 & 22.215 & $1.5931 / 2$ & 14 & $+40^{\mathrm{h}}$ & $-7^{\mathrm{i}}$ \\
\hline 1685 & 24.281 & $1.606 .5 / 8$ & 15 & & +7 \\
\hline 1686 & 23.421 & $1.6065 / 8$ & $14 \frac{1}{2}$ & & -3 \\
\hline 1687 & 22.635 & $1.5531 / 16$ & $14 \frac{1}{2}$ & & \pm 0 \\
\hline 1688 & 23.155 & $1.5885 \%$ & $14^{1 / 2}$ & & \pm 0 \\
\hline 1689 & 22.385 & $1.511 \%$ & 15 & & +3 \\
\hline 1690 & 22.430 & $1.5595 / 8$ & 14 & & -7 \\
\hline 1691 & 22.531 & $1.5715 / 16$ & 14 & & \pm 0 \\
\hline 1692 & 30.988 & $1.6077 / 8$ & 19 & & +35 \\
\hline 1693 & 30.922 & $1.5697 / 8$ & 20 & & +5 \\
\hline 1694 & 42.428 & 1.575 & 27 & & +35 \\
\hline 1695 & 45.831 & $1.5811 / 4$ & 29 & & +7 \\
\hline 1696 & 41.576 & $1.6047 / 8$ & 26 & & -10 \\
\hline 1697 & 44.831 & $1.612^{3 /} / 16$ & 28 & & +8 \\
\hline 1698 & 37.255 & $1.5591 / 8$ & 24 & & -14 \\
\hline 1699 & 53.202 & $1.582 \%$ & 34 & & +42 \\
\hline 1700 & 30.757 & $1.6131 / 2$ & 19 & & -44 \\
\hline 1701 & 38.153 & $1.6075 / 8$ & 24 & & +26 \\
\hline
\end{tabular}

Tab. 1: Nominal tax burden in Česky Krumlor, 1657-1669, 1682-1701

Sources: Vú - čg, I 4 L $\alpha, 62,63,64,65$; see also tables 1, 2, 3, 3.1, and 7 in S. SAnder-Faes, Herrschaft und Staatlichkeit, p. 191, 196, 200, 203, 222 (all sums in Rhenish fl.).

(a) Sums of all taxes paid by the composite Eggenberg dominions Český Krumlov (contributions and Terminsteuern).

(b) Median of the no. of osedly of the Eggenberg dominions, which incl. the incorporated entities.

(c) Nominal tax burden, based on (a) and (b) per osedlý and calendar year.

(d) YoY (year-on-year) denotes the change in percentages relative to the year before; there are no data for some years, denoted with „n/a“.

(e) No osedly data in 1662 and 1667; here I used averages based on the years before and after, respectively. 
(f) Osedly data from January through September 1683, as the cadastre revisions, in effect from 1 October, 1683, resulted in a significant reduction in the no. of osedly (c. $39 \%)$ for the entire Eggenberg dominions, which affected the average tax burden per osedly $(\mathrm{c})$ and YoY changes (d) accordingly.

(g) Osedlý data from October to December 1683; see also (e).

(h) YoY change (d) relative to the no. of osedly' from January through September 1683 (f).

(i) YoY change (d) relative to the no. of osedly from October to December 1683 (g).

While it is generally assumed that contributions, in Petr Mata's words, eventually „became the real core of the estates appropriations ${ }^{\text {"25 }}$, this particular category, with the exception of the tax hikes during the war of $1663 / 64$, remained essentially flat throughout the second half of the $17^{\text {th }}$ century and only started to increase markedly after $1699 .{ }^{26}$ Given the overall increases in the Habsburg monarchy's expenditure during the „Great Turkish War" (1683-99) and the successive War of the Spanish Succesion (1701-14), this may seem counterintuitively at first, however, massive tax increases were achieved by levying substantially more and higher additional taxes: Between 1682 and 1701, the Eggenberg tax records document 50 different tax categories that were due on 144 dates. Extensive documentation, including both taxation records as well as a large amount of correspondence, allows for the detailed assessments of how much and in which categories taxes were paid as well as how the tax burden changed over time. Analysis of Bohemia's two basic tax categories - monthly military contributions and taxes with fixed due dates - in the greatest possible detail revealed their equally composite nature, of particular importance with regard to their relative and changing shares of war financing. ${ }^{27}$ More contentious, but equally intriguing, is the notion that the promulgation of a revised cadastre in the

P. MAŤA, „Unerträgliche Praegravation“, p. 165.

26 Despite the military tax hikes in the $1660 \mathrm{~s}$ - contributions rose to $32080 \mathrm{fl}$. (1661), $31909 \mathrm{fl}$. (1662), $32442 \mathrm{fl}$. (1663), and reached $42820 \mathrm{fl}$. (1664) - the median contribution per year from 1657-1670 and from 1682-1701 was $18861 \mathrm{fl}$. (average: c. 21,976 fl.), and military taxes did not rise significantly again before 1699 (27 300 fl.); what did increase, and massively so, were the additional taxes, or Terminsteuern: their median over the same period was $9404 \mathrm{fl}$. per calender year (average: c. 11,930 fl.), yet they ranged from $1548 \mathrm{fl}$. (1682) to $27371 \mathrm{fl}$. (1695), an increase of just shy of $1800 \%$; note that additional taxes between 1682-1691 averaged 4469 fl. (median: 4615 fl.) before first almost tripling to $12244 \mathrm{fl}$. (1692), eventually reaching their peak in the second half of the $17^{\text {th }}$ century at $27371 \mathrm{fl}$. (1695), which is roughly equal to a sixfold increase relative to four years earlier; sources as in tab. 1.

27 Apart from the information quote in tab. 1, above, see also the extensive documentation in S. SANDER-FAEs, Herrschaft und Staatlichkeit, p. 497-506; just to cite one example: from 1682-1691, each year saw four of these additional tax positions, from 1692-1701, the corresponding number (median and average) was ten. 
early 1680 s modified not only the tax base but also affected both nominal and effective tax rates. In for the first time providing tax data on the crucial decades between the 1650 s and the early 1710 s, this serves as the foundation for the following elaborations and offers a yardstick to the widespread $\mathrm{Vi}^{-}$ enna-focused reconstructions of Habsburg fiscal history. ${ }^{28}$

Having established the basic framework of Bohemian tax administration, the focus in Chapter 5 then shifts to the lord's manor during the half-century of Český Krumlov serving as princely residence (1665-1710). ${ }^{29}$ It investigates the flows of „,ommunication“, which analytically includes both information and tax money, from the vantage point of the lord's court and his officials. This enables, first, the introduction of an analytical model that differentiates between communication "above“ and „below" the level of the lordship. In a second step this approach is augmented by asking questions about the legitimacy of communication - what, exactly, constituted „official“ information and how did it differ from „unofficial“ ways and means? In combination, the reconstruction of these interlinkages and their administrative practices allow for a more balanced assessment of the individual actors' room for manoeuvring, in turn providing an innovative new perspective on the „ongoing human production" that is the ever-changing nature of the social order. ${ }^{30}$

Chapter 6 builds on preceding chapters and takes a close look at those individuals who kept the princely estate and, by extension, the Emperor's war efforts, up and running. It builds on the analytical model developed in the previous chapter to differentiate between the varying communicative situations (regular vs. singular dealings; the directions of the flow of information) and illustrates the findings with two case studies. The first example revolves

28 Cf. the totals for the entire Habsburg monarchy that, even in the most recent syntheses, continue to be based on dated and methodically not unproblematic studies, in T. Win Kelbauer, Ständefreiheit I, p. 479 (based on J. BÉrenger, Finances, p. 293-294; IDEM, À propos, p. 228); identical references in T. Winkelbauer, Nervus, p. 182, although supplemented by references to Franz von Mensi, Die Finanzen Österreichs von 1701 bis 1740 nach archivalischen Quellen dargestellt, Vienna 1890, p. 745; and P. G. M. Dickson, Finance and Government under Maria Theresia (1740-1780) I-II, Oxford 1987, here vol. II, p. 385-386; cf. further Michael Hochedlinger, Austria's Wars, p. 38 (references to J. Bérenger, Finances); idem, The Habsburg Monarchy. From 'Military-Fiscal State' to 'Militarization', in: Ch. Storrs (ed.), The Fiscal-Military State, p. 54-94, at 64; note that even in the most recent synthesis by T. Winkelbauer, Krieg, p. 38, this is (indirectly) mentioned as the source given is IDEM, Nervus, p. 182, giving the argument a certain circular flavour.

29 If not indicated otherwise, cf. S. SANDER-FaEs, Herrschaft und Staatlichkeit, p. 239-295.

30 Conceptually based on James CArey, Communication as Culture. Essays on Media and Society, New York 2009, p. 14-21; the inclusion of horizontal and vertical communication is based Wolfgang REINHARD, Geschichte der Staatsgewalt, Munich 2002, p. 183-235, on the asymmetric power relations between princes and their administrators p. 132-137, on " uncontrolled organisational growth [literally 'Wildwuchs']", p. 139; the final quote is from Peter L. Berger - Thomas Luckmann, The Social Construction of Reality. A Treatise in the Sociology of Knowledge, London 1966, p. 69. 
around the aspirations of the two Cistercian monasteries of Vyšší Brod and Zlatá Koruna, both incorporated fiscally into the Eggenberg domains, but repeatedly tried to reassert their independence, which, of course, the prince strenuously objected to. The second case study details the travails of one individual, Gregor Daubsky, whose personal misfortunes and his inability to pay his arrears caused the princely administrators considerable troubles. Examples like these, which both transcended the narrow territorial confines of the Eggenberg domains, reveal the many links between local issues, regional entanglements, and supra-regional consequences. ${ }^{31}$

\section{Fig. 2: Analytical Categories}

\begin{tabular}{|c|c|c|c|}
\hline Situation & destination: centre & destination: sideways & destination: periphery \\
\hline $\begin{array}{l}\text { recurring } \\
\text { instances }\end{array}$ & $\begin{array}{l}\text { - clear hierarchies } \\
\text { - clear course of action } \\
\text { - clear-cut power relations }\end{array}$ & $\begin{array}{l}\text { - multiple courses of } \\
\text { action } \\
\text { - multiple power relations }\end{array}$ & $\begin{array}{l}\text { - clear hierarchies } \\
\text { - clear courses of action } \\
\text { - clear-cut power relations }\end{array}$ \\
\hline $\begin{array}{l}\text { individual } \\
\text { instances }\end{array}$ & $\begin{array}{l}\text { - clear hierarchies } \\
\text { - optional courses of } \\
\text { actions } \\
\text { - multiple power relations }\end{array}$ & $\begin{array}{l}\text { - exchange between equal } \\
\text { actors } \\
\text { - multiple power relations }\end{array}$ & $\begin{array}{l}\text { - exchange between } \\
\text { unequal actors } \\
\text { - optional courses of } \\
\text { actions } \\
\text { - many exceptions }\end{array}$ \\
\hline
\end{tabular}

Source: S. SANDER-FAES, Herrschaft und Staatlichkeit, p. 310.

Chapter 7 presents a detailed case study of how these structural issues discussed so far played out in practice. ${ }^{32}$ While acknowledging the special - and well-known - roles played by Leopold I's Jewish financiers, this chapter focuses exclusively on the brief reign of Joseph I (1705-1711) and explores the previously unknown story of how the emperor grew so desperate for additional funds that he, and perhaps counter-intu- itively so, undermined the centralisation achieved by his predecessor. Cash-strapped, Joseph turned to the Bohemian diet, which approached a consortium of Jewish financiers from Würzburg and Frankfurt who advanced the considerable sum of 1,333,333 fl. to the emperor. In exchange, Joseph offered future Bohemian tax revenues as collateral, thus de facto „outsourcing“ his regal rights of tax collection to a (foreign) third party.

31 If not indicated otherwise, cf. S. SANDER-FAes, Herrschaft und Staatlichkeit, p. 297-352.

32 If not indicated otherwise, IвIDEм, p. 353-408.

33 This episode, unconnected to the Oppenheimer affair (background in T. Winkelbauer, Ständefreiheit I, p. 522-524; IDEM, Nervus, p. 198-199), on which there is no record in the Eggenberg tax records, is hitherto unknown and does not appear in the otherwse superb biography of Joseph I by Charles W. Ingrao, In Quest and Crisis. Emperor Joseph I and the Habsburg Monarchy, West Lafayette 1979; likewise, this episode is omitted in J. PeкAř, České katastry, passim; and does neither appear in T. Win kelbauer, Ständefreiheit I, p. 409-529, nor in P. MAŤa, „Unerträgliche Praegrava- 
Tab. 2: Terminological Warfare, 1675-1709

\begin{tabular}{llllllll}
\hline & $\begin{array}{l}\text { Docu- } \\
\text { ments }\end{array}$ & Military $^{\mathbf{c}}$ & „urks $^{\text {“d }}$ & $\begin{array}{l}\text { Executi- } \\
\text { on }^{\text {e }}\end{array}$ & Debts $^{\text {f }}$ & Taxes $^{\text {g }}$ & \\
\hline & no. $^{\text {a }}$ & p.a. $^{\mathbf{b}}$ & & & & & \\
\hline $\mathbf{1 6 7 5 - 7 9}$ & 105 & 21 & 37 & & 3 & 4 & 4 \\
\hline $\mathbf{1 6 8 0 - 8 4}$ & 129 & $25-6$ & 21 & 10 & 2 & 12 & 26 \\
\hline $\mathbf{1 6 8 5 - 8 9}$ & 89 & $17-8$ & 12 & 15 & 1 & 8 & 17 \\
\hline $\mathbf{1 6 9 0 - 9 4}$ & 117 & $23-4$ & 9 & 16 & 3 & 13 & 26 \\
\hline $\mathbf{1 6 9 5 - 9 9}$ & 118 & $23-4$ & 12 & 10 & 5 & 8 & 6 \\
\hline $\mathbf{1 7 0 0 - 0 4}$ & 93 & $18-9$ & 8 & & 10 & 37 & 13 \\
\hline $\mathbf{1 7 0 5 - 0 9}$ & 221 & $44-5$ & 21 & & 19 & 78 & 66 \\
\hline
\end{tabular}

Sources: Vú - čg, I 4 L $\alpha, 62,63,64,65$, and 66; n = 872 individual documents of varying length; note, first, that the no. in (a) does not represent the entirety of all documents as some of the sources were undated; sources without dates only appear, if their content allowed for a more or less unambiguous, content-based dating; and, second, that all more or less „regular“ tax positions (such as the monthly contributions) as well as those instances related to the affair described in $\mathrm{Ch} .7$ are not included here, which was done for pragmatic reasons: the documentation of the latter dealings are so extensive that their inclusion would alter the findings (too much); see also S. SANDER-FaEs, Herrschaft und Staatlichkeit, p. 449-450.

(a) No. of individual documents in each five-year period.

(b) Calculated annual average no. of documents; note that these are calculated yearly averages convey a certain impression of the increasing war-induced stresses: tax and associated pressures between 1675-1704 occupied officials in Český Krumlov on average every 2.5 weeks; between 1705-1709, this had increased to almost weekly incidence.

(c) Key terms in this category: infantry; militia; recruits; soldiers; troups; (cavalry) horses; artillery; board and lodging; not included here are those terms that are specified in ( $\mathrm{g}$ ).

(d) Key terms in this category: Turk, incl. translations and equivalents in other languages.

(e) Key terms in this category: execution (impounding), incl. announcements; officials charged with the execution; background information in B. Rieger, Zrízeni krajské, vol. I, p. 326-338; J. Peкаг̆, České katastry, p. 95-96; and P. Mă̌A, „Unerträgliche Praegravation“, p. 177-178.

(f) Key terms in this category: debts; security; seizure (execution); residual amount; liability; arrears.

(g) Key terms in this category: anticipation; subsidies; poll taxes; beverage taxes; wealth tax; other unspecified extraordinary taxes.

tion", even though the latter stresses the necessity of large-scale enquiries into the Bohemian diet's financial affairs on p. 184-185. 
Hardly surprisingly, this arrangement caused considerable friction between all parties in Český Krumlov, Prague, and Würzburg, shedding new light on the interrelated consequences of dynastic ambitions and state disintegration in wartime, thereby offering a rare glimpse into the financial dealings of the Bohemian diet. ${ }^{33}$

The final chapter asks the seemingly simple question who paid for the emperors' ambitions? ${ }^{34}$ In recent decades, the number of publications detailing the interrelationship between warfare and state formation has grown considerably. ${ }^{35}$ Most studies, however, mention the drastic consequences for the taxpaying subjects only in passing; in the case of Bohemia within the Habsburg monarchy, most recent scholarship builds on these assumptions and ascribes the massive increase in taxation to "tremendous improvements in efficiency", accompanied by „serious consequences for both military and society“. ${ }^{36}$ Chapter 8 attempts to ameliorate this lacuna by putting the princely subjects at the centre of the investigation, addressing the following issues: How did the administrators describe, refer to, and treat the commoners living on the Eggenberg estates? And, perhaps more crucially, how did the subjects themselves consider their own state of affairs? While insights into the former are based on tax records, correspondence, and visitation reports, the latter are derived from a number of petitions and interrogation protocols. A quantitative survey of key terms such as „debts“, „repossession“, and „military“ rounds off the chapter (see Tab. 2), in turn allowing for an assessment of how far administrative language and practices too became "mobilised“. This combination of qualitative and quantitative approaches allows for a more inclusive reconstruction than either group of sources would provide on their own.

\section{War and Consequence - Conclusions}

My study on the Habsburg monarchy around 1700 highlights the interrelated forces that contemporaneously drove both state integration and state disintegration, which refers to the loss of social cohesion and control over certain key areas and policies, were (are), not unlike the two-faced god Janus, two aspects of the same phenomenon. ${ }^{37}$ It is based on two premises that differ markedly from the overwhelming majority of studies on this subject matter

34 If not indicated otherwise, S. SANDER-Faes, Herrschaft und Staatlichkeit, p. 409-466.

35 Its starting point in the late $20^{\text {th }}$ century was Peter B. Evans - Dietrich Rueschemeyer - Theda Sкосрог (edd.), Bringing the State Back In, Cambridge 1985; the ensuing discussions are summarised, including bibliography, in B. Kroener, Kriegswesen, p. 62-72; Joachim Bahlcke, Landesherrschaft, Territorien und Staat in der frühen Neuzeit, Munich 2012 (= Enzyklopädie deutscher Geschichte 91), p. 59-77; see also notes 7 and 8 for additional references.

36 Exemplified by P. MaŤA, „Unerträgliche Praegravation“, p. 173.

37 E.g., day and night, war and peace, creation and desctruction; cf. Fritz Graf, Ianus in: Hubert Cancik - Helmuth Schneider (edd.), Der Neue Pauly. Enzyklopädie der Antike, vol. V, Gru-Iug, Stuttgart 2015, especially, p. 858-861. 
that employ a one-point perspective, that is, looking „down“ from a courtly centre to the "lower" layers of the body politic. By contrast, I examine the implications of approaching the same developments from an inverse perspective based on these two premises: First, individual actions and structural developments convey different consequences for central institutions vis-àvis those occurring contemporaneously in more remote areas; and, second, I contend that the forces that drive state integration, understood as an elite-driven process emanating from the imperial capital, were also responsible for state disintegration, which refers to the loss of social cohesion and control over certain key areas and policies.

Circumstances such as a state of war brings with it the tendency to more and more concentrate influence and power in the hands of fewer and fewer individuals and institutions while non-essential activities receded, i.e., a certain type of state integration in the centre was accompanied by increasing disintegration and loss of cohesion on the lower levels, which in turn underscores the essentially composite nature of early modern mano- rialism. While the emperor and his inner circle attempted to deal with war-induced stresses, the consequences of their actions loosened the connections between state and society - which is exactly what happened in Český Krumlov. It would not seem too far-fetched to imagine that these routine, day-to-day issues could not be identified throughout early modern Europe (if more studies focused at state development from further "down“ than the diets). As examplary studies by Lucien Febvre, John Elliott, and Darryl Dee suggest, we can arrive at new insights into early modern statehood by focusing on local knowledge and practices embedded in their regional contexts. ${ }^{38}$ This, however, implies going beyond the (ideal) typological considerations based on the selective reading of, among others, Max Weber and Otto Hintze, whose works constitute the foundations of the questionable interpretative marrying of Brewer's „fiscal-military state" thesis to the eventual emergence of "modern" statehood that have come to all but dominate historiographic discourse, which is especially true with respect to most German-language studies: Whereas

38 Lucien Febvre, Philippe II et la Franche-Comté. Étude d'histoire politique, religieuse et sociale, Paris 2009 [first 1911]; John H. Elliott, The Revolt of the Catalans. A Study in the Decline of Spain (15981640), Cambridge 1964; Darryl DeE, Expansion and Crisis in Louis XIV's France. Franche-Comté and Absolute Monarchy (1674-1715), Rochester 2009 (= Changing Perspectives on Early Modern Europe 13).

39 E.g., John Brewer, Revisiting The Sinews of Power, in: Aaron Graham - Patrick Walsh (edd.), The British Fiscal-Military States (1660-c.1783), London 2016, p. 27-34, at p. 30: „[M]y larger aim was to open up an historical discussion of the English state in the context of recent social scientific writings about the role of the state in the context of European history. The project was conceived as a tentative beginning rather than an end, and was... far from complete." Cf. what many of his acolytes have done, exemplified by, among other things, the changes in the priorities of the original concept in the essays by Nina Hartly (on Russia) or Michael Hochedlinger (on the Habsburg monarchy) in Ch. STORRs, The Fiscal-Military State. 
the majority of them these days seek to integrate the early modern Habsburg monarchy within the larger framework ascribed to Brewer, both he and I remain quite skeptical of such unidimensional and quasi-teleological interpretations. ${ }^{39}$ In looking at „my“ sources that detail the crucial role of local actors, regional interlinkages, and the disintegrating consequences that warfare had on state formation, my analysis of the consequences of almost perpetual war between the 1680 s and the 1710s from this perspective reveals both the unidimensional nature of some interpretations as well as the need for more nuanced, inclusive approaches. In providing a complimentary perspective to the rather one-sided historiographical mainstream, I discuss the larger ramifications of the nexus of warfare and taxation in a comparative manner. In offering a first glimpse into, in John Brewer's words, „how fiscal and administrative arrangements function", as opposed to labelling certain states as such, my study contextualises and re-positions the Habsburg monarchy within current academic debates, drawing out what was distinct and what was similar to the experience of other major European monarchies. ${ }^{40}$

40 J. Brewer, Revisiting The Sinews of Power, p. 31 (emphasis in the original). 


\section{Stephan Sander-Faes}

\section{Lordship and State Formation}

\section{Bohemia and the Habsburg monarchy from the Thirty Years' War to Charles VI}

\section{(Abstract)}

This essay focuses on the crucial role of the lordship in Habsburgs' attempts of state formation from the Thirty Years'War to Charles VI. During these decades, Austria became a great power, mostly from accident, helped by the unintended consequences of an ill-conceived Ottoman assault on Vienna in 1683. This essay focuses on the usually overlooked by-products of state formation in early modern composite monarchies, administrative confusion and social disruptions. Using the example of Bohemia and contrary to most books available, which employ a top-down perspective, my approach is based on two different premises: First, individual actions and structural developments convey different- and differing-consequences for central institutions vis-à-vis those occurring contemporaneously in more remote areas. And, second, state integration, understood as an elite-driven process emanating from a centre, is accompanied by countervailing and at times opposing trends whose consequences only increased with geographical distance. War thus gives rise to a certain kind of state formation, which was accompanied by the contemporaneous disintegration and loss of cohesion outside the centre. This essay explores, how, as the government tried to cope with war-induced stresses, its actions started to tear apart the administrative and social fabric that held society together.

KEY WORDS:

fiscal-military state; state deformation; fiscal-financial history; composite lordship; Český Krumlov 